\title{
POLITICIZATION OF SENSIBILITY: THE SPECTACLE EFFECT OF COLONIAL EMPIRE IN THE 1930S SEOUL
}

\section{A B S S T R A C}

This paper aims to analyse the phenomena of the consumption culture in terms of the spectacle effects of the colonial empire, which were unprecedented prosperity in the 1930s in Seoul. The phenomena could be interpreted as the politicization of sensuality. The spatial change intensified the colonial differentiation of city that was segregated into the Southern Village for Japanese and the Northern Village for Koreans. It facilitated the modern homogenization of the urban space. Especially, department stores were invigorated as a powerful apparatus for consumer capitalism, inviting Koreans to Japanese street, transcending the spatial border of the colonial segregation. Manipulating the exhibition techniques of department store, Japanese Empire built up the visually attractive self-representation image, encouraging the colonized to experience the fascination of modem urban culture as crowds or spectators in the street. The spectacle of the Empire made new lines of cultural distinction based on the differentiation of social stratum inside the colonized community. 


\section{INTRODUCTION: CITY IN COLONIAL MODERNITY}

The 'modernity' phenomenon occurs on the grounds of urban space. It implements new systems of variability and liquidity, change and innovation, growth and development, destroying and dismantling the traditional life in a flash. It is a change in the macroscopic and collective aspect, and at the same time, a change in the microscopic and individual aspect. The modernity in terms of individual experience is a process in which the modernity of collective institution is reproduced in daily urban life. 'Urban experience' is the key driving force of the production of modern subjectivity. The fundamental details include artificial 'urban built environment', 'fashion and trend of capitalist product economy', and 'change and speed' that replace the long duration of rural environment and agricultural economy, and slow rhythm of circulation.

This paper is an attempt to focus more on the elocutionary behavior of 'the subject of desire' than the structural power of 'disciplinary power', and more on the hegemonic aspect of consumer culture than institutional compulsion, in determining the urban phenomenon of 'colonial modernity'. In other words, the main social venues where people of colonial modernity are produced are not closed spaces such as schools, factories, prisons or police stations, but are rather display windows of department stores or open streets of the city where modern boys and girls are striding down. ${ }^{1}$ Our awareness of problems shifts from observation and surveillance to display and watching, or from compulsion and repression to agreement and desire. This change in theoretical perspectives can be referred to as a shift from the 'panopticon' model to 'spectacle' model. ${ }^{2}$

The urban space of Seoul has been sustained as a colonial 'dual city' throughout the Japanese colonial era (1910 1945), facing a significant change in its qualitative attributes around the mid-1920s. This change is closely related to Japan's colony industrialization policy and the mainland's large consumption capital entering the colony. This paper will analyze the change brought by urban space to the urban society of the colony by focusing on consumer culture of the 1930s such as department stores and cafes in Seoul.

In general, department stores are referred to as an essential system of modern capitalism, with which the capitalist economy drags human beings into being the main agents of consumption, mediated by their consumption desire for products. This is the same in colonial Korea as well; thus, department stores were not just commercial facilities, but they played a variety of roles as the 'heart of the city' and 'pier of the streets', with state-of-the-art devices of consumption and trend, cultural facilities, entertainment and amusement facilities, and society galas. 
We aim to define the urban space of Seoul in the 1930s as a dominant system of colonial power, and explain the main aspects of its spatial change. To this end, we will analyze the changing aspects of urban space caused by complete colonial consumer capitalism in the 1930s by focusing on department stores and Bonjeong (Honmachi in Japanese) commercial district. Furthermore, we will examine how the changes in the urban space and colonial consumer culture transformed the urban experience and independence of the colonists.

\section{URBAN CULTURE AND SENSIBILITY}

Seoul in the 1930s must have been a city of civilization that was showing off glory. It was a different and unfamiliar space that ruthlessly destroys identity. Such chaotic change was imprinted on the minds of the people as a shocking experience. Writers such as Yi Sang or Gubo had already visualized in their novels the appearances of Seoul in the colonial era and the extensive shock. The urban civilization reflected by them was a capitalist society transplanted by strong heteronomy. Such urbanization had the dual attributes of the breathless transformation of appearance and the rooted colonial contradiction. Seoul at the time was already undeniably inside the process of urbanization, modernization and industrialization. A typical example could be that the city population exceeded the rural population.

With the urbanization in progress, new sensibility called 'urban sensitivity' began to take form. There appeared urban people and intellectuals who fully accept the aspects of urban life. Urbanites are people who live a completely different pattern of life from rural areas, and who can also experience the 'urbanity' of urban space. Urban experience led Koreans to be aware of the dual structure of obsession and denial of tradition. Moreover, desire for material things created the schizophrenic self-deprecation of humans, capitalized within the lagging economic conditions.

As streetcars were introduced in Seoul in 1898, its urban space changed rapidly. Streetlights were being set up on the Jongno crossroads in 1900. The most thriving street at the time was Jongno between Namdaemun and Dongdaemun. However, the streets of Myeongdong and Chungmuro created by the Japanese people gradually became the center of Seoul.

What dominated the urban culture of Seoul was the wave of commercialism that began to emerge on a large scale. It alerted the colonial society to the rules of trends, fashion, advertising and consumption via mass media representation, and gave people a taste of the world of civilization, individualization and 
desire, away from the world of traditions, morality and customs. ${ }^{3}$ With the relocation of the Japanese General Government Building to Gwanghwamun (1926), the shift from the 500-year dynasty capital to the administrative capital of a colony was wrapped up for the time being, after which consumer culture began to flourish.

The changes in urban space of Seoul in the 1930s have three distinctive characteristics. First, there was a functional division of urban space, including economy-centered and politics-centered division. Second, the population was increasing more rapidly around those flowing into the outskirts of the city. Third, the unemployment rate of Korea including Seoul reached its peak in the depression in the early 1930s, and then decreased in the mid-1930s. By the mid-1930s, the appearance of the traditional 500-year capital Hanyang of the Joseon Dynasty barely remained; instead, the aspect of metropolitan policy of capitalist began to unfurl, characterized by the remarkable hierarchical polarization of the rich and the poor, horizontal expansion of urban lands, and vertical change of the urban landscape.

Grounded on the change in the industrial structure, growth of the urban middle class, expansion of the consumer market and growth of purchasing power, followed by the implementation of the 'Joseon industrialization policy' in the 1930 s, there began to occur great changes throughout the shopping districts, focusing on Seoul's most thriving area 'Bonjeong' or 'Honmachi' in Japanese. In short, this can be summarized as the movement to expand the shopping districts in Seoul, or the urban business districts. There are two aspects that characterize this movement. First, it led to an expansion of the business districts followed by construction and extension of big department stores; second, the entertainment business spread out rapidly among the urban middle class. These changes have been made with a gradual ripple effect throughout the entire city, and they were mostly led by the biggest and most thriving district of adult entertainment in Seoul, namely 'Bonjeong'. The goods sold in Bonjeong were like symbols of 'modern boys' and 'modern girls' who led the trends at the time, and they were accepted also as objects of consumption for individuals as well as symbols of modernity.

This tendency of the city's consumer capitalization did not just bring change to space, but also brought change to the subject. It is necessary to analyze two conflicting matters to examine such aspects: one is the 'material system of consumer capitalism' that brings the urbanites to the venue for capitalist consumption, and the other is the "changing aspects of the urban subjects in the colonial society' that respond to the above. 


\section{SPECTACLES OF THE EMPIRE}

\section{System of Consumer Capitalism}

Koreans began to position themselves as buyers at the Bonjeong shopping district since the early $1920 \mathrm{~s} .{ }^{4}$ Since then, there was a full-scale interaction between Japan's consumption capital and Korean colonists. ${ }^{5}$ The goods that led the trend of urban pop culture during this period are magazines, films, fashion and gramophones. The major material systems of consumer culture that brought changes to the urban space are department stores, cafes and theaters. We aim to focus on two aspects here.

First, these consumer goods that were popular in colonial Korea were, unlike the premium 'Western-style' cultural goods directly imported from the West and consumed by the Japanese upper class and elites, 'Japanized' cultural goods that were acculturated to the public taste of Japan through the Taishō period. A typical example is the culture of transforming cafes into "ero-gro' 6 decadent entertainment spaces, despite the fact that they had been introduced originally as social scenes for intellectuals. Cafes were established as the 'cradle of culture' where artists and writers who led the latest trends and culture of the Meiji period gather together, along with young people who admire them. However, upon entering the Shōwa period after the Taishō period, cafes were transformed into popular Japanized bars that represent the entertainment district. ${ }^{7}$

In the similar context, department stores have transformed into places with a unique Japanese character in the popularization process after the Taishō period. Department stores in the Meiji period had been places for a high-class urban hobby. However, after the Great Kanto earthquake, the scope of customers expanded from a few privileged billionaires to the general public including ordinary salaried workers. As a result, department stores became the 'hall of consumption' and 'hall of vanity' that arouses the desire for consumption through the phantasmagoria ${ }^{8}$ of the display windows overflowing with massproduced goods. The aspect of a compact urban amusement facility that includes an amusement park or event hall was also emphasized, acting as the 'hall of amusement' that provides leisure for families. 'The most remarkable trend among the distinct characters of Japanese department stores is the fact that they have become an 'institution of pleasure'.' The exterior of department stores at the time took the form of 'architecture as media', displaying the advanced consumer culture widespread in the city. ${ }^{9}$

The second thing to note is that as a result of the spatial expansion of imperial media, the colonial urban space experienced dual changes. With the increasing 
investment and development of big Japanese capital, the urban space of Seoul experienced modern capitalist homogenization on one hand, while on the other hand spatial discrimination and polarization became more intense between areas with concentrated development and areas alienated from development. Namchon and Bukchon of Seoul, namely Bonjeong and Jongno, started out as spaces that were qualitatively different from each other, as the former was the street of Japanese people and the latter was the street of Korean people. With the general homogenization of urban space due to capitalist urban development, the colonial dual city transformed into a homogenous yet differential space in which the qualitative difference can revert to quantitative difference of land value and rent. As Jingogae, which had been the 'base of Japanese invaders', transformed into Bonjeong, the hub of consumer culture and the civilized empire's 'space of spectacles', the ethnic boundary between Namchon and Bukchon gradually changed into the boundary of capital that separated development and alienation. The concentration of theaters in Namchon was noticeable in Seoul. Korean people were forced to visit Bonjeong (or Honmachi) to have a taste of the empire's civilization'. The phenomenon of 'Honbura'10, which emerged as a custom of 'pilgrimage' popular in the Korean society, was an outcome of such spectacles of the empire and discriminative homogenization of colonial urban space.

In general, introduction of capitalist urban development and consumerist popular culture transforms a space into an object of speculation and trading by removing the qualitative attributes like historicity and place from urban space. The urban space of Seoul experienced discriminative homogenization due to consumption based on taste in 'Hakurai' (importation), followed by the inflow of big consumption capital from Japan. The capital expanded the consumer market beyond the ethnic boundaries. The political discourse on the reality of ethnic discrimination faltered, whereas the discourse on the expansion of channels for consumption capital emerged.

\section{Department Stores and Cafes}

The Japanese stores of Namchon Jingogae that secured commercial supremacy in Seoul had already positioned themselves as seductive spaces that simulate and satisfy the modern consumption desires of Koreans as well. Among them, 'department stores' were particularly viewed as the symbol of consumptive temptation. Department stores in the streets of Seoul are the places where new consumer culture flourished over the barren life of colonial Korean people. Department stores not only sold products but also dreams of cultural life. The world's first department store was Bon Marché opened in Paris, France in 1852. 
Department stores depend on increasing merchandise turnover with low rate of profits, and tempt consumers to enter the store freely without the obligation to purchase something. They replace the conversations, which had mediated transactions in traditional stores, with wordless price tags. The perception of customers who stroll by the products piled high on display becomes a panorama similar to that of the passersby traveling on railroad or strolling down the main streets. Department stores are what focused on the movements of the crowds gathered on railroads and station squares, and linked them with business skills.

Department stores have been the symbol of modern consumer civilization. There were total 6 department stores established in Seoul during the colonial era. It is remarkable that Japanese people opened as many as 5 department stores in Seoul where the population was only 400,000 , leading a significant growth of the business district and enjoying the 'golden days of department stores'.

It was only in the 1920s when department stores began to be established and managed in earnest. Mitsukoshi Department Store started out as Mitsukoshi Gohukuten, which is the Seoul office of Japan in 1906. Mitsukoshi Department Store designed, constructed and completed a department store with the total floor area of 6,000 $\mathrm{m}^{2}$ in October 1930, with a rooftop garden on the roof. That store is still now being used as the main building of Shinsegae Department Store. Department stores of the Japanese shopping district were appealing and fantastic temptations of consumer culture for Koreans, while they also stimulated their ethnic inferiority. ${ }^{11}$ Hwashin Chain Store was established as Hwanshin's new business in 1934, which later expanded and became Korea's leading chain stores with 350 stores. Moreover, elevators were commercialized in Hwashin Department Store, which was reconstructed in 1937. The sensibility fever in the 1930s first began from the display window of that department store. As the escapist journey of a helpless schizophrenic of a colony boils down to the 'soaring' on the roof of Mitsukoshi Department Store in the novel Wings $^{12}$ by Yi Sang(1910-1937). Department stores at the time were a symbol of the richness of the empire and the power of advanced civilization.

We aim to focus particularly on two aspects here. One is the fact that the Japanese products sold in department stores operated by the big capital of Japan enjoyed immense popularity among Korean people, and the other is the fact that there was a department store based on the native capital of Korean people that competed with the overwhelming attack of the big Japanese capital. 
The most advanced thing in urban space was 'café'. Since cafes were modern, they were deviant; and as they were deviant, they were spaces that form a modern city. Spaces that newly emerged in the city such as cafes, bars and tea rooms formed a new culture in the 1930s. The fact that both cafes and tea rooms sold coffee was something they had in common; but while tea rooms could not sell alcohol, cafes offered alcohol as well as waitress services. The exotic interior design as well as the mere fact that women dressed in 'modern' clothes waited on customers was enough to turn cafes into an open 'space of sexual service'. Accordingly, intellectuals who had considered themselves as modern people, as well as 'westernized people', 'modern boys' and 'modern girls' all gathered in cafes.

Cafes were new spaces of consumption, established by leisure that was created amidst industrialization, and were also spaces of communication to express resistance to the society. Furthermore, they were spaces where people who wanted to lead the latest fashions could be acknowledged for their differentiated styles from others. Cafes could be used only by the Japanese and upper-class Korean people around Japanese settlements, but the scope was gradually expanded to Joseon settlements. The reason why intellectuals at the time visited cafes was because there were modern waitresses in cafes to sing with, sit down and talk about life and studies, and enjoy liberal academic traditions as well as free love with modern women. The intellectuals' agony and confusion between modernization and colonial reality were fully revealed in such cafes. Admiring the superior Western culture and feeling relative superiority for enjoying it, as well as the contradictory behaviors to overcome the inferiority toward Western culture by emphasizing tradition were all expressed in various ways.

These cafes were spaces that were closely related to artists in the modern days. Artistic activities in the medieval times mostly had the character of a joint event of the village with some social purpose. There had been spaces for community cultural life in each village unit. However, as these conditions gradually vanished along with the fall of feudalism, these spaces were replaced by cafes. In the $18^{\text {th }}$ century of the West, artists broke away from the financial support of lords or aristocrats to form an invisible market economy with readers. By losing the opportunity to directly meet with readers or the audience, artists came to need contact with a different world, along with interaction among one another. Due to this demand, cafes became the most essential place for artists to interact in the space of a modern city. ${ }^{13}$ 
Cafes became a staging area for artists. The early 1930s was the golden days of cafes; there were 1,000 cafes in Seoul only. After Nagwon Café opened and succeeded in 1931, cafes sprung up everywhere in Jongno, the center of the Korean society, which expanded the base of café users. Cafes were "consolation like an oasis in the middle of the desert for young Seoul citizens, as only a 10jeon coin provides Brazilian coffee and service of beautiful waitresses." 14

\section{Homogenization of Urban Space}

Since some 'Western-style buildings' like foreign official residences and churches began to be constructed in Seoul, the city's landscape and skyline changed. After the Japan-Korea Annexation, Japan established many buildings due to increased service needs. Buildings that were big at the time were the Japanese General Government Building (1926), Bank of Korea (1912), Seoul Station (1925), and Seoul City Hall (1926). These are mostly constructed in modern styles with individual forms of the modernist buildings. In the colonial style, the plane and elevation compositions are grounded on aesthetic principles, emphasizing perfect proportion, symmetry and harmony. The first thing invaders to do in their colony is building big and imposing buildings. Architecture is fundamentally a product of power. ${ }^{15}$ Western-style buildings secured their places as symbols of the city, and transformed the structure of the streets. Along with the shoddy Japanese-style or Japanese and Western-style housing, buildings with Neo-baroque, Renaissance and Eclecticism techniques used in government offices at the time established themselves as the new landscape of the city.

What formed the city's image, along with those new buildings, were the 'signboards' on the streets. Signs were one of the urban images that predicted the changing times more quickly than others. They also raised people's interest in design and typography. Another new urban scene is 'advertisements' hanging up all over the streets.

Signs were also the most conspicuous part of the external characteristics of cafes. At the time, the 'modern' trend was converted to images on the streets through the physical substance of signs. Signs were the medium that turned colonial and contemporary urbanity into objects of specific experiences. The writings on the signs were mostly in Chinese characters, along with some Kana characters of Japan as well as English, which gave the Korean streets an exotic sensation. The 'neon signs' introduced on the signs and displays brought a complete transformation of the urban street landscape. Neon signs were 
first used for outdoor advertising in Korea in 1932. Neon signs are nighttime advertising media that attract consumers walking by or standing into the store. First invented in 1911, neon signs shed light on the nights of Seoul by the 1920s.

'Railway' of the Japanese colonial era has ambivalent elements of modernization and colonial rule. Railway stations are passages to bring in the goods and civilization, while also being the staging areas of collapsed farmers and unemployed urbanites. It is the assembly area of the ambivalence of Seoul. Railway was a new traffic route that connects one city to another, and it accelerated the urban growth at an unprecedented speed. It was a symbol of separation of time and space, as well as compression of time and space. Accordingly, railway not only caused the population fluctuation but also created new forms in human relations. As the means of travel changed to railway, people were won over by the production system and transformed into one of the public and simple consumers from being personal individuals. Moreover, railway saved time by enabling people to cover a long distance in a short period of time. This saving of time indicated saving of space. Standardization of time demanded by railway eliminated different regional times and replaced them with standardized, physical dynamic and homogenous time of abstraction. Railway provided the visual experience of perceiving time and reality as spectacles. This indicated the mechanization of time. Railway travelers have limited chances to turn their heads around to look at the scenery. What they see is a scene of spectacle that brushes past and then disappears. As scenery quickly brushes past, the amount of visual impressions that must be processed by visual perception increased drastically.

Three 'streetlights' were first set up on the Jongno crossroads on April 10, 1900 , but it was only in 1935 when streetlights were widespread in the city. What played a significant role here is the production of big 'plate glass' that can be used on display windows of stores and use of 'mirrors' on the display. As a growing number of anonymous middle-class customers replaced former customers, the importance of display windows of stores further increased. The windows with bright light pouring on the big plate glass were like big stages, the streets like theaters, and passersby like the audiences. This is a nighttime scene of the big city Seoul. Passersby strolling down the main streets see the products displayed inside the stores through the huge plate glass, as if the scenery outside the window brushes past on a train. This gaze of the people strolling along the arcades is none other than the 'flowing gaze'. 


\section{BROKEN IDENTITY}

\section{Divided Space}

The optimistic state of affairs such as the end of World War I, emergence of the League of Nations, and Wilson's self-determination, which excited the colonial intellectuals over the rosy ideals, quickly cooled down after 1921. Accordingly, the prospects for cultural sophistication and humanitarianism became gloomy, and cultural movements were divided into two directions. One was to 'move to the left' and proceed toward class movement, and the other was to move on to capitalist ability fostering movement based on the social evolution theory. ${ }^{16}$

What the consumer-capitalist cultural goods mean for consumers, particularly colonists, is to seek temporarily refuge in the fantasy of goods away from the deprivation and helplessness of the reality. In other words, it is to imagine and experience the 'power of civilization' through foreign products. Therefore, what is important for them is not the utility value of the product itself, but the symbol of new power called 'Hakurai' (importation), and the emblem of civilization. Colonists, who cannot break free from the 'nonsense' of colonial reality, found psychological consolation in such 'imaginary world of symbols'.

But the realistic issue here is the fact that due to the absolute entry barrier of monetary exchange value of products, there were only a very small minority of colonists who could have access to such 'allurement' of the empire on a daily basis. These very few people that enjoyed the modern urban cultural goods imported from Japan appeared repeatedly in magazine articles that described the scenes of thriving streets in Seoul at the time. 'Honbura' that caught the eyes of observers and the main customers that enjoyed shopping at department stores were mostly women and students. In other words, people who played a central role in urban popular culture in the 1930s were middle-class women and students. They were the only ones with the requirements for purchasing goods of popular culture, such as leisure in life, habitation in the city, and cash buying power. However, under the colonial capitalist economic structure, the middle class was an anxious being with no stable grounds for reproduction.

It was not easy for most common people to enjoy the lifestyles of modern boys and girls, Hakurai and fashion, or Honbura and nighttime picnic under cherry blossoms. Thus, they created a new identity that mixed ethnicity with publicness in daily life, by designing various different cultural systems from extremely traditional ways to the latest 'cheap' imitations. In other words, the 
upper limit on cultural goods produced by colonial consumer capitalism was limited by the colonial character; but in the reality of urban society where an absolute majority of urbanites were suffering from famine and poverty, the lower limit was boundless. As such, the spectrum of how urbanites existed was broad and diverse. And those boundaries were clearly set up according to the 'spatial split lines' of the colonial dual city.

'Cafes', which represented the latest entertainment culture at the time, were located in Bonjeong or Honmachi mostly as stores managed by the Japanese. On the other hand, most 'restaurants' were located in districts where Koreans lived, and was managed by Koreans. This 'restaurant' category includes various forms, but most of them were pubs selling makgeolli or Korean dark rice wine. There was the space of northern village where pubs scattered the mazelike backstreets, and the space of southern village filled with the dazzling lights of cafes with neon signs. One ironical issue here is that while the former was an exclusive space for Koreans, the latter was not limited to Japanese people only. Modern boys and girls enjoyed Honbura, and revealed their changed bodies by displaying that they have become 'civilized' and 'Japanized' in the civilized space of the Japanese people.

On the hidden side of the boom of Seoul's consumer and entertainment culture with the 'golden days of department stores', there was a dark shadow of absolute poverty. The allurement of colonial capitalist civilization was absolutely limited in terms of the scope of its effect. Most colonists were deprived of their spending power, far from the venue of such allurement, and were living their life as neglected 'spectators'. Their world was of colonial blending and imitation, and what determined its method from the root was monetary value. The night market of Jongno was always filled with cheap imitations, and the streets were overflowing with all kinds of people wearing such diverse combinations of imitations. For the civilized people, they were 'ridiculous' and 'nonsense'; but such 'cultural hybridity' was a frank representation of the colonists' life.

\section{Changing Aspect of Urban Subjects}

Intellectuals are originally those who have ambivalent attributes. They have the desire to climb up the social ladder using their many years of education, and commonly reveal their will to resist to the conventional system for the lowerclass people in the material and spiritual sense. The contradiction of these conflicting desires appears to be bigger in the distorted reality of a colony. The subtle conflicts of this contradiction might have been the true colors of Korean intellectuals. ${ }^{17}$ 
Since the opportunity to become elite under the Japanese rule and be appointed as a government official was monopolized by a few pro-Japanese people, it was difficult for intellectuals to have satisfaction in the material and spiritual sense. Thus, Lumpen Intellectuals in Korea faced alienation not just in the economic sense but also in the complicated ethical and social sense. Many escapist intellectuals despised people who took advantage of the distorted modern reality, while rationalizing their solitude and passiveness. In other words, "when the desires they fantasize and portray are not satisfied, they wandered around cafes, bars, revues (light amusement plays), jazz, eroticism, and salons to escape the reality. The decadence of wandering on the streets and the hedonism of nihilists did not originate from mere poverty or personal taste, but were rather characterized by resistance to the society." "18

The number of Koreans visiting Japanese stores at Jingogae increased, and there emerged a new generation graced by urbane manners, namely 'modern boys' and 'modern girls'. They roamed around the shopping districts and department stores to fulfill their desire of consumption, and sat around cafes to discuss the solitude of urbanites. They were conducting artistic activities by strolling along the streets of Namchon dressed in eye-catching outfits and exchanging jokes in tea rooms. The epitome of Lumpen Intellectuals as outsiders were their colleagues.

But on the other hand, small Korean traders in their downfall groaned everywhere; and the urban poor and the unemployed roamed around the streets in search of jobs, as the byproducts of the colonial agricultural policy. Then again, for young intellectuals and new women, the city was a symbolic place, an object of admiration, and an exit. Seoul was the closest city to modernity, but was the farthest place from their reality.

\section{Flowing Gaze and People Taking Walks}

The work that best depicts the modern city of Seoul in the Japanese colonial era is A Day in the Life of Kubo the Novelist $t^{19}$ by Park Taewon, one of the best-known modern boys of the time. It is a novelette serially published in Joseon Jungang Ilbo for a month in 1934. Park Taewon carried around his college notebook at all times and scribbled the urban scenery and customs as well as the aspects of the crowds. He confessed that he could not write the novelette with imagination alone, so he walked around the downtown area to see the actual thing with his eyes. ${ }^{20} \mathrm{He}$ grandly announced that his work is an analysis and interpretation of modern customs based on systematic research 
and investigation of life at the time. A Day in the Life of Kubo the Novelist is about the author's persona and novelist Kubo, who gets out of his house at noon, wanders around the streets of Seoul, and returns home at 2 a.m. the next morning. He named this methodology as 'Modernology'. It includes the institutions and customs of 1930s Seoul such as tea rooms, cafes, streetcars and department stores, and embraces the cultural landscape of people living there, such as relationships, love, reading and gossips.

As he walks along the streets of Seoul, he lets his imagination run wild about the petty everyday adventures, mental errantry, urban landscape and people. The novelette is set on the paths of isolation and wandering, the streets of Seoul where intellectuals roamed about. This is reflected by the images of going out or taking a walk, which are common motifs of A Day in the Life of Kubo the Novelist. Charles Baudelaire (1821-1867) said that 'modernity (modernité)' is characterized by not only separation from tradition and sensitivity toward new things, but also awareness of the dizzy time discontinuity in the moments that brush past. ${ }^{21}$

Modernism that revolts against the bourgeois values and enlightening rationality is an aesthetic reaction to such conditions of modernity. This questions the values claimed by modernity in the past, such as beliefin reason and progress, obviousness of the subject, objectivity of reality and transparency of representation. At the same time, it maximizes the modern attitude of the fundamental introspection on everything and oneself, while embracing the sensitivity toward reality that approaches in discontinuity and fragmentation. Modernism is an 'urban art', and it clearly found its place of settlement in the 'city'.

Modernity, a $19^{\text {th }}$-century phenomenon, was a product of the city ${ }^{22}$. It is responding, in a fictional or ideological form, to the new and complicated social beings that pass by strangers, in the atmosphere where there are mental stimulations that make people sensitive in the face of day. It is dominated by exchange of money and daily necessities, suppressed by the intensifying individualism and economy, and controlled by the atmosphere that reveals the character of being extremely expressive in the context of individuals and family, while seemingly indifferent in public. The key figures that embody such modernity are leisurely flâneurs, pleasant wanderers, or inert strollers. These flâneurs observe yet do not interrupt, and gaze yet do not truly look. Like watching products on display, flâneurs symbolize the privilege and freedom of roaming around the public places of the city while watching others. They embody the view of greedy and erotic modernity. ${ }^{23}$ 


\section{CONCLUSION:}

\section{EMPIRE ON DISPLAY, AND THE CROWD LOOKING ON}

The colonial urban space was a theater screening the spectacles of the empire that shows off the power of civilization, as well as a stage of a tragic life producing the desperate drama of racial discriminative polarization. ${ }^{24}$ Considering the duplicity of such colonial space, this paper aimed to reveal what political and social effects have been brought to the colonial society by the material systems such as department stores and cafes, which are characterized by the consumer culture of economic capitalism. One is the characteristics of the material systems of consumer capitalism, and the other is the response from the colonists. As a result of analysis, the former was mainly characterized by the fact that it acted as the media of empire that was 'depoliticized' and became a 'spectacle', represented by 'Hakurai (importation)'; and the latter was mainly characterized by the fact that the main agent of enjoyment was actually limited in the colonial society, which resulted in the 'cultural hybridity' and 'crack of collective identity' in the colonist society.

It was necessary to 'civilize' the Korean habitation as the spatial base in order to eradicate the political expression of collective identity of the colonists, in which colonist power is the source of anxiety, and to accomplish an ultimate assimilation. However, the limited power of the Japanese material civilization was not enough to allure and attract the participation of most colonists that were alienated from the benefits of civilization. Furthermore, the amplification of the social contradiction --- the rich get richer while the poor get poorer --- in the big city of Seoul due to capitalist industrialization and urbanization further intensified the crack of colonial urban society. The empire devised the scheme of 'politicization of sensibility'. In other words, they maximized the ruling effect with the spectacles of urban space, and as a result, the colonists watched the spectacles of civilization as the crowds on the streets. However, despite the claim for assimilation with such grandiose ideology, the empire could not embrace most of them as anything more than by-standing 'spectators'. Most colonists could only roam around the 'cheap night markets' scattered with colonial imitations of the empire's civilization, and could not actually obtain their rights from the empire of civilization as well as the empire of goods.

The colonial society was split up between those who were graced by the spectacles of the empire produced by big consumption capital and those who were not, according to the capitalist polarization of the rich and the poor. In the end, the national topsiders grew farther away from the chaos and impoverishment of the ethnic reality by choosing to become 'civilized'. 
Lee Gyeong-hoon, "Yobo, Mobo, Gubo : Life of a Colony," in Yonsei University Institute of Korean Studies, Everyday life of the Korean people under the Japanese colonial rule (Seoul: Hyean, 2004), 219.

The former is represented by Michel Foucault's Discipline and Punish: the Birth of the Prison (New York: Random House, 1975), while the latter is represented by Guy Debord's The Society of the Spectacle, translation by Fredy Perlman and Jon Supak (Detroit: Black \& Red, 1983). In the U.S., idealism collapsed and Americanism emerged in the 1920s, characterized by the revolution of manners and morality. It was an era dominated by new moral laws created in the postwar disillusionment, during which the young men and women who had claimed radical theories of class or politics many years ago came to support new ethics and express sexual desire. Jeon Woo-yong, "Formation and Transformation of Seoul Namchon Shopping District under Japanese Colonialism", Seoul Namchon: Time, Place, People (Institute of Seoul Studies, 2003), 196.

This trend of change clearly appeared in the publication market as well. Since the mid-1920s, 'reading materials for hobby' that are clearly tools for capitalist entertainment began to emerge, such as Byel-geon-gon, that replaces political magazines like Gaebyeok in the early 1920s. In 1920, 
Dong-A Ilbo and Chosun Ilbo increased the number of pages and separated their film and sports articles as well as women's column. It was also around this time when pornographic publications imported from Japan via mail order began to be massively consumed in the urban society. Cheon Jeong-hwan, Modern Book Reading (Seoul: Blue History, 2003), 198. easily be referred to as 'the era of ero gro nonsense'. This expression is short for 'erotic, grotesque, and nonsense', and it was widely popular in various fields such as newspapers, magazines, literature, drama, films, gramophones, and records.

Hashizume Shinya, Birth of Modern City: Street of Osaka, Street of Tokyo (Yoshikawa Kobunkan, 2003), 42-66.

Phantasmagoria was a form of theatre which used a modified magic lantern to project frightening images such as skeletons, demons, and ghosts onto walls, smoke, or semi-transparent screens, frequently using rear projection. The projector was mobile, allowing the projected image to move and change size on the screen, and multiple projecting devices allowed for quick switching of different images. Invented in France by a Belgian physicist in the late 18th century, it gained popularity through most of Europe throughout the 19th century.(from Wikipedia)

Hashizume Shinya, Birth of Modern City: Street of Osaka, Street of Tokyo, 107-110.

'Honbura' refers to the act of looking around Honmachi, a thriving street of Seoul. It originates from the word 'Ginbura' that refers to strolling (burabura) the street of Ginza in Tokyo at the time in Japan.

Su-hyeon Mok, "Cultural Space of Namchon", Seoul Namchon: Time, Place, People (Institute of Seoul Studies Symposium Sourcebook), (Institute of Seoul Studies, 2000), 150.

This is a story by Yi Sang published in the magazine Jo-gwang in 1936. It is a typical work of psychological or intellectual literature in the 1930s. The story expresses inner anxiety and sense of identity, and shows the despair about the society and history as well as dissolution of identity. Steve Bradshaw, Cafe Society (Weidenfeld \& Nicholson, 1978).

Eul-han Kim, "Gyeongseong Yahwa”, Byel-geon-gon, 1930, 86.

Jeong-dong Kim, Remaining History, Disappearing Buildings (Daewonsa, 2000), 185-186.

Chan-seung Park, "Study on Korean History of Modern Political Ideas: Theory of Ability Fostering Movement by the Right-wing Nationalists," in Seoul: Historical Criticism (1992), 202-233.

Young-taek Park, "Colonial Urban Space and Art," Journal of Korean Modern \& Contemporary Art History, Vol. 10 (2002): 202.

Jin-won Choi, "Intelligentsia Theory", Chosun Ilbo, March 5, 1932..

Taewon Park, A Day in the Life of Kubo the Novelist (Moonji Publishing Company, 1998).

Hye-sil Choi, "Effects of Urbanization of Gyeongseong on Korean Modernism Novels in the 1930s," Journal of Seoul Studies, Vol. 9 (1998): 186.

Charles Baudelaire, The Painter of Modern Life, "Modernity," (1863).

David Harvy, The Condition of Postmodernity (Oxford: Basil Blackwell, 1989), 25.

Griselda Pollock, "Modernity and the Spaces of Feminity", trans. by Lee Sun-ryeong, The Issues of Art After Modernism (Noonbit Publishing, 1999), 462-463.

Baek-yung Kim, "A Theoretical Exploration on Colonial Urbanism," Society and History, Vol. $72(2006): 172$. 
Baudelaire, Charles. The Painter of Modern Life and Other Essays, ed. and trans. by Johnathon Mayne, London: Phaidon Press, 1995.

Bradshaw, Steve. Cafe Society. Weidenfeld \& Nicholson, 1978.

Cheon, Jeong-hwan. Modern Book Reading. Seoul: Blue History, 2003.

Choi, Hye-sil. "Effects of Urbanization of Gyeongseong on Korean Modernism Novels in the 1930s." Journal of Seoul Studies, Vol. 9 (1998).

Choi, Jin-won. "Intelligentsia Theory”, Chosun Ilbo, March 5, 1932.

Debord, Guy. The Society of the Spectacle, translated by Fredy Perlman and Jon Supak, Detroit: Black \& Red, 1983.

Foucault, Michel. Discipline and Punish: the Birth of the Prison. New York: Random House, 1975.

Harvy, David. The Condition of Postmodernity. Oxford: Basil Blackwell, 1989.

Hashizume, Shinya. Birth of Modern City: Street of Osaka, Street of Tokyo. Yoshikawa Kobunkan, 2003.

Jeon, Woo-yong. "Formation and Transformation of Seoul Namchon Shopping District under Japanese Colonialism.” Seoul Namchon: Time, Place, People. Institute of Seoul Studies, 2003.

Kim, Baek-yung. "A Theoretical Exploration on Colonial Urbanism.” Society and History, Vol. 72 (2006).

Kim, Eul-han. "Gyeongseong Yahwa”, Byeolgeongon, 1930.

Kim, Jeong-dong. Remaining History, Disappearing Buildings. Daewonsa, 2000.

Lee, Gyeong-hoon. "Yobo, Mobo, Gubo : Life of a Colony", Yonsei University Institute of Korean Studies, Everyday life of the Korean people under the Japanese colonial rule. Seoul: Hyean, 2004.

Mok, Su-hyeon, "Cultural Space of Namchon”, Seoul Namchon: Time, Place, People. Institute of Seoul Studies, 2000.

Park, Chan-seung. "Study on Korean History of Modern Political Ideas: Theory of Ability Fostering Movement by the Right-wing Nationalists." In Seoul: Historical Criticism (1992).

Park, Taewon. A Day in the Life of Kubo the Novelist. Moonji Publishing Company, 1998.

Park, Young-taek. "Colonial Urban Space and Art." Journal of Korean Modern \& Contemporary Art History, Vol.10 (2002).

Pollock, Griselda. "Modernity and the Spaces of Feminity", trans. by Lee Sun-ryeong, The Issues of Art After Modernism. Noonbit Publishing, 1999. 
Kompletno istraživanja objavljeno je u knjizi The indispensable excess of the aesthetics: evolution of sensibility in nature (Neizostavni višak estetike: Evolucija senzibiliteta u prirodi, Lexington 2015).

KLJUČNE REČI: EVOLUTIVNA ESTETIKA, DARVIN, BIOSEMIOTIKA, ZOO-POETIKA, AESTHESIS, ZOO-ESTETIKA, EVOLUCIJA

\section{OBECANJE MEDIJSKE ARHEOLOGIJE Nadežda Čačinovič}

Medijska arheologija nudi novi i neophodan alat za suočavanje sa mnoštvom fenomena koje tako neselektivno - anahrono ili na druge načine - prepoznajemo kao umetnost i klasifikujemo kao umetnička dela. Rad pokušava da naglasi razliku u poređenju sa srodnim gledištim: teorije kulturne transmisije, materijalnosti kulture, logike estetskih režima itd. Moglo bi se nazvati "mediji pre medija" (i prati Kitlera (Kittler)) ili kopati sa Zilinskim u "Duboko vreme medija" (Deep Time of the Media) sa dobrom vezom prema "istoriji pristupa čula" ili ići pravo sa Jusi Parikom i Erki Huhtamom (Jussi Parikka, Erkki Huhtamo) i koristiti "medijsku arheologiju”: ali je uvek priznanje protejske prirode umetnosti i arhitekture.

KLJUČNE REČI: MATERIJALNOST KULTURE, ISTORIJA ČULA, MEDIJI, KULTURNA TRANSMISIJA

\section{FORMA I ZNAČENJE U ARHITEKTONSKOJ TEORIJI Jale Nejdet Erzen}

Često je arhitektonska teorija bilo jasno izražena propisanim stavovima o tome šta bi arhitektura trebalo da bude, pre nego stavovima formulisanim od istorijskih iskustava i primera arhitekture. U ovom radu ću pokušati da ponudim čitanje arhitektonske forme gledajući istorijski primer iz klasične otomanske arhitekture i savremene primere, pokazujući kako različite arhitekture tretiraju formu. U primerima Sinanove arhitekture, simboli su istraživani u odnosu na kretanje, urbani sklop, religiju i moć. Ideja je da će ova analiza ponuditi razumevanje značaja arhitekture u okvirima ljudskog iskustva i urbanog konteksta kojii dopire izvan strukture i funkcije.

KLJUČNE REČI: ARHITEKTURA, SINAN, FORMA, ZNAČENJE, STRUKTURA, TELESNI ODNOSI

\section{POL ŠIRBART I UTOPIJA OD STAKLA}

\section{Tyrus Miller}

Ovaj rad će razmotriti arhitektonske spise nemačkog ekspresionističkog pisca Pola Širbarta (Paul Scheerbart), sa fokusom na njegovoj fascinaciji staklom kao arhitektonskim i metaforičkim materijalom. Diskusija je o Širbartovom arhitektonskom traktatu Arhitektura stakla (Glass Architecture), njegovom romanu Siva tkanina (The Grey Cloth) i srodnim tekstovima o arhitekturi stakla. Širbart predstavlja alternativnu tradiciju unutar arhitektonskog modernizma, koja gleda na staklo kao na konstruktivan materijal koji predstavlja modernost kroz izlaganje strukturalnih elemenata, takođe u službi komfor forme prema funkciji. Širbart, nasuprot tome, smatra staklo nosiocem boje i multiplikatora svetlosti, koje je video kao sposobnog da transformiše čovekovu okolinu i ostvari pozitivne efekte na pojedince i kolektive. On je video svetlost kao kulturnoformativnu, a arhitekturu stakla kao sredstvo kojim izgrađeno okruženje može da poveća moderni kulturalni utopijski potencijal. Takođe, ukratko ću razmotriti i uticaj Širbarta na anarhističkog arhitektu Bruna Tauta (Bruno Taut) i na razmišljanja Valtera Benjamina (Walter Benjamin). 
POLITIZACIJA SENZIBILITETA:

EFEKAT SPEKTAKLA KOLONIJALNOG CARSTVA 1930-IH U SEULU

\section{Joosik Min}

Ovaj rad ima za cilj da analizira fenomen potrošačake kulture u smislu efekata spektakla kolonijalnog carstva, koji su bili prosperitet bez presedana 1930-ih u Seulu. Ovaj fenomen se može tumačiti kao politizacija čulnosti. Prostorna promena je pojačala kolonijalnu diferencijaciju grada koji je bio podeljen na Južno selo za Japance i Severno selo za Koreance. Ovo je olakšalo modernu homogenizaciju urbanog prostora. Naročito su robne kuće bile okrepljene kao moćan aparat za potrošački kapitalizam, pozivajući Koreance na japanske ulice, prevazilazeći prostornu granicu kolonijalne segregacije. Manipulacijom izložbenim tehnikama robne kuće, japansko carstvo izgradilo je vizuelno privlačnu sliku, podstičući kolonizovane da iskuse fascinaciju modeme urbane kulture kao gomila ili gledaoci na ulici. Spektakl carstva napravio je nove linije kulturne distinkcije na osnovu diferencijacije društvenog sloja unutar kolonizovane zajednice.

KLJUČNE REČI: EFEKAT SPEKTAKLA, URBANI PROSTOR, KOLONIJALNI GRAD, POTROŠAČKA KULTURA, ROBNA KUĆA, SEUL

ESTETIKA KAO POLITIKA:

\section{MISLI O ARHITKTURI NESLAGANJA}

Helen Tatla

Doprinoseći debati za demokratsku artikulaciju urbane sredine, ovaj rad se fokusira na reinterpretaciju odnosa između razmišljanja i percepcije u Kantovom Drugom trenutku analitike lepog, Žaka Ransijera. Ransijer tvrdi da disenzualna operacija u Kantovoj definiciji lepog uključuje superimpoziciju koja transformiše datu formu ili telo u novo. Društvena emancipacija za Ransijera postaje estetska stvar, stvar raspadanja tela animiranog od strane određenog uverenja. Kada gubitak destinacije implicitan u estetskom iskustvu, kako je objasnio Ransijer, remeti način na koji tela uklapaju svoje funkcije u društveni poredak, onda se stvara politički efekat. Estetski efekat pretpostavlja disidentifikaciju. U estetskoj zajednici, politička subjektivizacija se zasniva na procesu disidentifikacije. Osim toga, ponovno razmatranje modernosti za Ransijera znači vraćanje na Šilerovu ideju estetskog obrazovanja čoveka koje je nastalo u Kantovoj Analitici lepog. Možemo raspravljati sa pozivanjem na arhitekturu neslaganja da kroz proces dislokacije, raspadanja i disidentifikacije, tradicija se otvara stalnoj transformaciji u nešto novo, uključeno u beskrajnu igru između potpuno različitih slojeva koji čine svakodnevno iskustvo. 